Article

\title{
Social Justice: Disparities in Average Earnings across Portuguese Municipalities
}

\author{
Vítor João Pereira Domingues Martinho ${ }^{1,2}$ \\ 1 Polytechnic Institute of Viseu (IPV), Agricultural School (ESAV) and CI\&DETS, Viseu 3504-510, Portugal; \\ vdmartinho@esav.ipv.pt \\ 2 Centre for Transdisciplinary Development Studies (CETRAD), University of Trás-os-Montes and \\ Alto Douro (UTAD), Vila Real 5000-801, Portugal
}

Received: 26 February 2019; Accepted: 15 April 2019; Published: 19 April 2019

check for updates

\begin{abstract}
An ever-ongoing discussion these days involves the disparities in monthly earnings across different genders, geographical locations, levels of education, economic sectors, and skills and careers, with various economic and social consequences. In fact, in a framework such as that in which we live in nowadays (with pertinent concerns about economic and social convergences across several indicators), investigating these disparities would be interesting in order to complement the basis that is considered for the design of social policies. There are few studies considering the approaches here developed for this topic. The objective of this study is to analyse the disparities in the average monthly earnings received by employees across Portuguese mainland municipalities over the period 2004-2012, considering as additional analysis criteria geographical location, gender, levels of qualification, levels of education, economic sectors, professional activities, and further qualifications. For this both a cluster and factor analysis were considered to better identify municipalities with similar characteristics and correlations among variables. The results show that the disparities in the monthly average earnings between the Portuguese municipalities are related to three indexes associated with gender, qualifications, and chosen professions. The findings presented are specific to the Portuguese framework; however, the approaches developed in this study may be applied in other contexts to explore the dynamics related with the topic of social justice.
\end{abstract}

Keywords: employees; wages paid; social justice; municipal clusters; uncorrelated factors

\section{Introduction}

The laws and rules for labour markets are, in western countries, often defined by social agreements between the employees labour union confederations and employers' confederations or other representative structures. Usually in these negotiations a desired objective, among others, is to find a balanced agreement between the labour union's intentions of increasing wages and improving employees' rights and the will of the employers in maintaining salaries and increasing their flexibility in the labour markets.

In this social concertation, another aspect is regarding the disparities in the wages paid with respect to gender, geographical location, level of education, and qualifications, and the economic sector where the employees develop their activities. This seems to be a discussion which has not yet been finalized and has relevant social and economic implications.

In fact, the disparities in the average earnings have consequences for the roles developed by the population both inside the family and in society, considering the importance of the income upon the daily pressures to define social position and status, namely in the definition of family tasks between husband and wife and in the organization of social groups. 
The economic consequences are not negligible when considering the importance of the employee's incomes in the dynamics of firms' locations and the availability of employment. With respect to this new economic geography, Fujita et al. (2000), among others, explain the economic implications of the disparities in wages received by employees.

Indeed, the new economic geography shows that locations with higher salaries attract more employees, and this attracts more firms to take advantage of a greater availability of employees that are also agglomerated consumers across small distances in circular and cumulative processes. Within these frameworks, firms and employees tend to concentrate on the same places, where wages play a relevant role for the workers and the reduction in transport and communication costs is a decisive factor of importance for the enterprises.

In these contexts, the objective of this study is to analyse the disparities in average monthly earnings for employees in the Portuguese mainland municipalities through cluster and factor analysis over the period 2004-2012. The main intention of this analysis is to bring more insight into understanding the differences in the average monthly earnings for Portuguese employees and find regions of Portugal with similar patterns for these problems. Finding Portuguese regions with similar incidences of several types of disparities (between genders, qualifications, professions, and economic sectors) will better support future policies in order to mitigate these social injustices. This research may prove to be an interesting contribution towards the definition of adjusted social policies for the convergences in wages paid, namely among genders and geographical locations. For the Portuguese context, it is urgent to find adjusted solutions for these social problems, namely to improve the levels of social justice and to promote a balanced development between the north and south and, specifically, between the coastal regions and the interior (where the asymmetries are indeed a concern).

This approach of factor-cluster analysis was considered to understand the relationships between the several variables (related with the disparities in average monthly earnings) in the explanations of several factors (indexes) and to obtain uncorrelated variables for cluster analysis, avoiding problems of multicollinearity. This was previously done through factor analysis. The cluster analysis brings about other insights, specifically by affording an understanding of the specific context for the variables considered in groups of Portuguese municipalities. The specific methodologies considered for each analysis will be explained deeper in the respective sections of this study.

There are few studies considering the approaches performed in this study for the subjects analysed (average earnings disparities). This study brings interesting insights for stakeholders, particularly policymakers. The work was developed for the Portuguese context, but may be applied to other frameworks.

\section{Literature Review}

Geographical locations have a significant impact upon the social realities of each country, region, or municipality, derived by local cultural, economic, and environmental dynamics (Batista-Foguet et al. 2004; Bernard and Saint-Arnaud 2004). The several dimensions of societies are interrelated, making it impossible to dissociate the social dimensions from the cultural and economic contexts (Mihokova et al. 2016). Of course, social capital, as a set of networks between people, has a definitive influence upon the other dimensions of society (De Dominicis et al. 2013), namely the location and performance of the economic activities (Garnsey and Heffernan 2005) and transmission channels of knowledge for innovation processes (Tappeiner et al. 2008).

The social realities and dynamics are diverse across and inside each location. However, the geographical factor is not the only variable with an impact upon social interrelationships (Saraceno and Keck 2010). To deal with these distinct social contexts in research studies, finding adjusted methodologies is crucial to obtaining pertinent results. Cluster and factor analysis are interesting tools for dealing with contexts where there is different cross-sectional statistical information interrelated with several sets of variables, as shown, for example, by Bernard and Saint-Arnaud (2004), Cernakova and Hudec (2012), and D'Ancona (2009). 
However, problems with cluster analysis involve questions related with the collinearity among the variables that may bias the results when considering that the correlated variables increase their weight in the clusters' definition, influencing the results in their direction, as stressed for example, by Mitchell (2009).

For Portugal, these methodologies with factor and cluster analysis were considered by several authors such as Sousa et al. (2003) who through factor analysis identified factors related with socio-professional characteristics, ageing of the population, and housing characteristics. The cluster analysis permitted for the identification of groups with different living standards.

In any case, the disparities in the average wage received by the employees have several social consequences in the organization of cities and countries, as shown by Armaș and Gavriș (2013) for Bucharest in Romania. The extreme social implications of the social differences, as a consequence of several social groups within unemployment and with low incomes, are well visible in diverse parts of the world, affecting social cohesion and the choice of the representative politicians (Aschauer 2016).

Sustainable societies need to find balanced relationships within the economic, social, and environmental dimensions, where employment and the labour markets have an important role in these interrelationships (Dilly and Hüttl 2009), as well as the asymmetric income distribution (Shaker and Zubalsky 2015). Unemployment is an unavoidable variable when the intention is to consider social dimensions in any study, considering not only its implications on the income of populations, but also on family organization (Fernandez et al. 2016). In these contexts, the existence of minimum income schemes is crucial to avoid complex situations of instability inside social dynamics, minimizing the consequences derived from the extremely competitive frameworks, where the economy is many times overvalued (Figari et al. 2013). Poverty and the risk of poverty are a concern for the European Union (Goedemé 2013); however, the current economic and financial situations across the several member states are proving difficult for creating an effective policy for these issues, namely in countries where the recent crises have had consequences for the population. Many social indexes stress the importance of variables such as employment, education, and income (Padilla et al. 2016).

There are many causes for the disparities in the level of average wages received by employees, such as gender, professional activity, and the level of education, among others. The level of education in current societies, which privileges social networks, skills, and qualifications, seems to be an important determinant in the distribution of the quality of life in European cities (Higgins et al. 2014). A similar approach was defended by Manitiu and Pedrini (2016) when stressing the implications of the interrelationships between wages and worker skills in the concentration of economic activity and the population within linked interactions.

These disparities stem from incomes which were increased mainly after the 1960s, with the changes in the economic organization in societies which promoted contexts favourable to service sector activities in detriment to industrial production (Kammer et al. 2012). There were various consequences among countries and regions and implications for the labour market and the environment (Stuczynski et al. 2009). In fact, the dynamics and performance of economic activities and sub-activities have implications for the evolution of societies. Each country and each region have their individual characteristics and sometimes some activities are unappreciated (Martinho 2016).

In any case, several organizations present in societies, from labour unions to employer organizations, may provide important contributions towards improving convergence and social cohesion. However, the participation of the populations within the several organizations is very low in some countries, as is the case in Portugal and in other Mediterranean European countries (Mascherini et al. 2011).

Here, public policies have a decisive role to play; however, sometimes the family contexts have more implications on gender disparities rather than social strategies (Castellano et al. 2018). Wage disparities have, in turn, their relevance inside the family unit (Pepin 2019), and implications for the roles taken on by the different family members, namely in terms of income share. In fact, the social contexts are interrelated with other dimensions, namely economic, and, consequently social policy design cannot 
be disassociated from the economic, cultural, and environmental strategies (Perugini and Pompei 2016). For example, inefficiencies in the labour market contribute, in some cases, toward earning disparities because it is often difficult to create new jobs and better remunerated ones (Castellano et al. 2017). On the other hand, the scientific literature shows that worker usually migrate from zones where the wages are lower to those with higher remuneration for labour (McCollum et al. 2017).

Balanced growth and development is crucial to promote social justice in any country. Usually there is a natural tendency for the appearance of socioeconomic asymmetries across the globe and inside each country (between regions) despite the design of several policies to increase the convergence between the different geographical units. Often, these asymmetries that appear for any reason sometimes become self-reinforced through circular and cumulative phenomena. The new economic geography (Fujita et al. 2000) explains these processes through the differences in salaries. In fact, regions or countries with higher salaries attract more population and usually the firms prefer to locate themselves in regions with greater consumerism, creating more employment there (attracting a wider population) and payment of higher wages and so on successively, promoting, in this way autonomous and self-reinforced phenomena. In general, these processes call for public policies to be minimized. This is why the supranational, national, and regional governments have serious difficulties in mitigating the regional asymmetries that are of special concern in European Union countries such as Portugal due to the agglomeration of the population in the coastal areas (namely around Lisboa region) and the desertification of the interior. This scenario brings about not only economic and social problems, but also environmental consequences. This framework shows the importance of multilevel public policies to reduce the geographical asymmetries and promote balanced and sustainable economic development and increase social justice. Here, well designed regional, social, and economic policies are crucial to bringing more socioeconomic convergence.

\section{Data Analysis}

Figures 1 and 2 presented as follows show values for the monthly average earnings (euros) for workers over the period 2004-2012 (average) and across the Portuguese mainland NUTS (Nomenclature of territorial units for statistics) II (namely because of the lack of statistical information for some island regions). These data were obtained from the Portuguese Statistics (INE 2017) and allow for a comparison of the monthly earnings among genders, typology of areas (urban or rural), and for the different sectors of activity (primary, secondary, and tertiary).

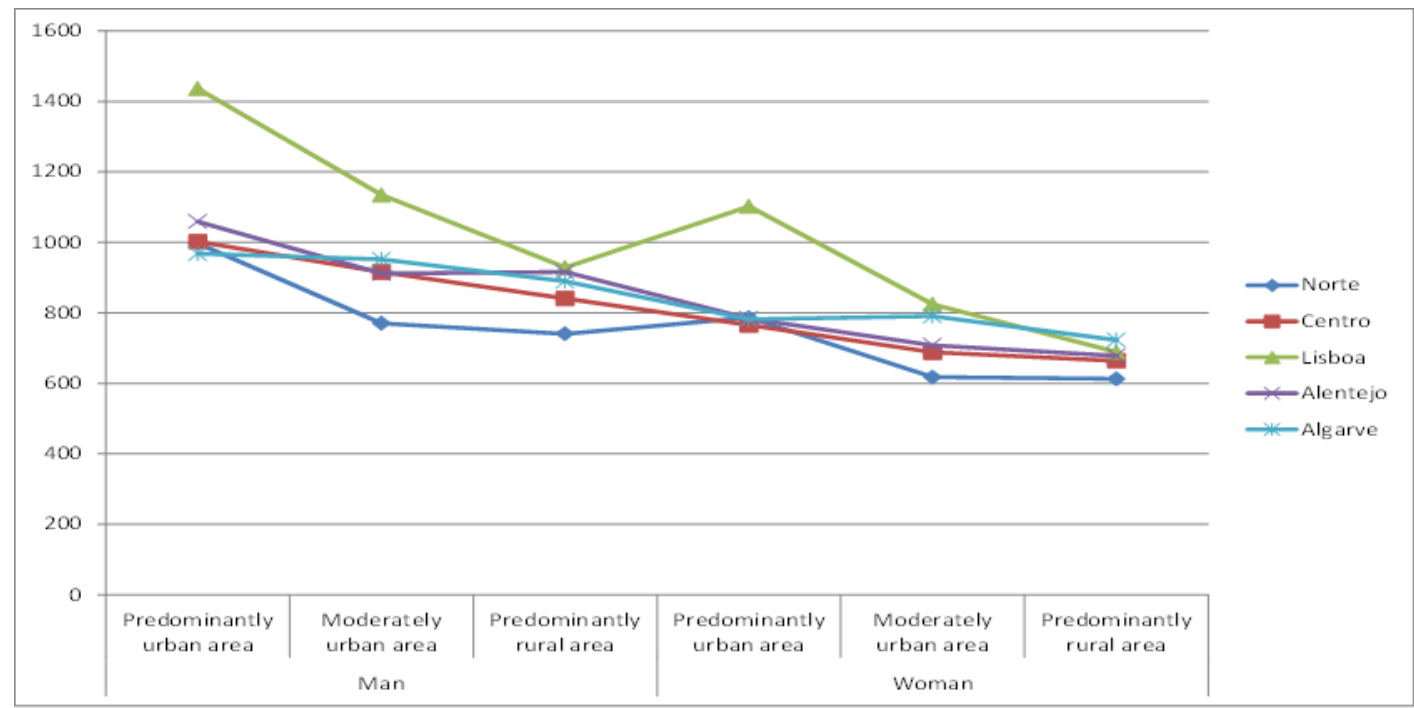

Figure 1. Monthly average earnings (euros) for workers over the period 2004-2012, across Portuguese mainland NUTS II, using the gender and the area typology as factors of comparison. 


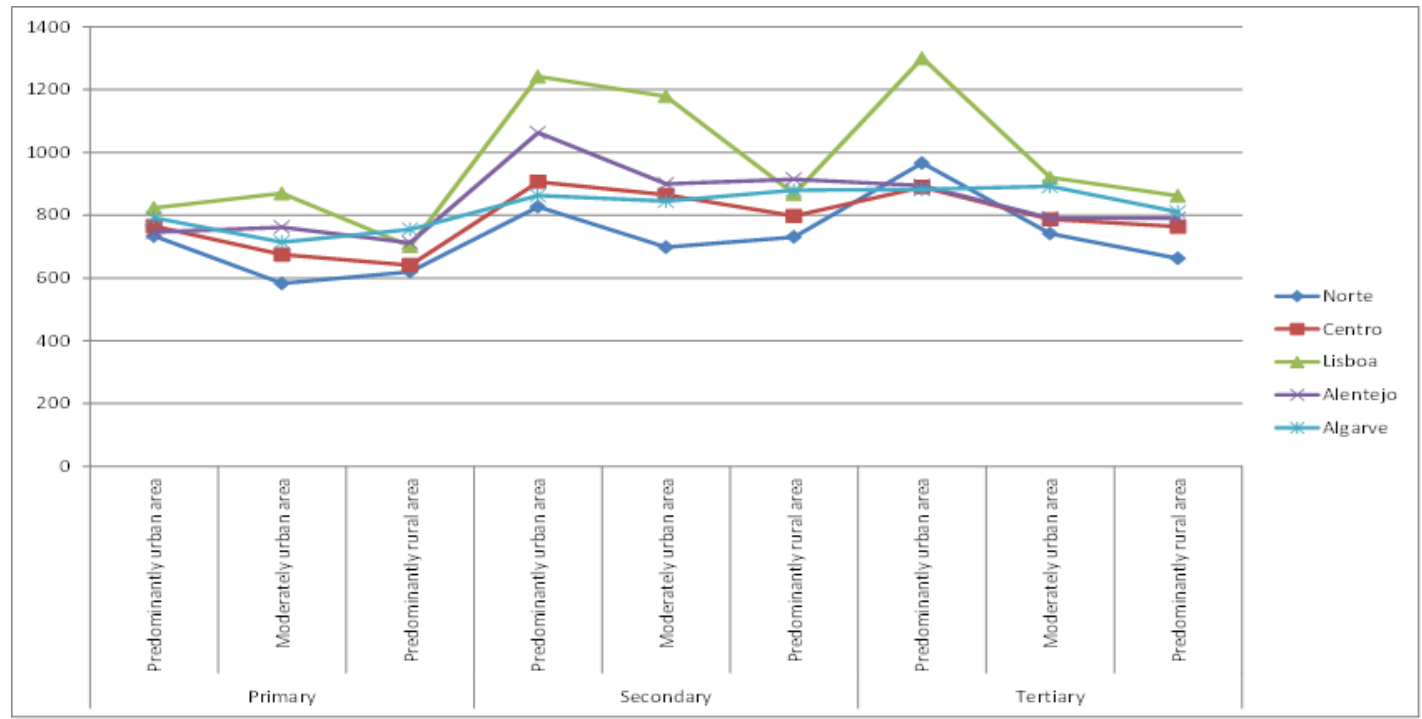

Figure 2. Monthly average earnings (euros) for workers over the period 2004-2012, across Portuguese mainland NUTS II, using the economic sectors and the area typology as factors of comparison.

Figure 1 reveals that in the Portuguese mainland NUTS II over the period considered, men received more than women and workers gained more in the urban areas than in the rural zones. The Norte is the region where the labour force earns the least and Lisboa is the region with a greater income for workers. In addition, for example, a man earns a monthly average of about $€ 1437$ in a predominantly urban area of Lisboa and a woman in the same region receives $€ 1102$. On the other hand, a man in a rural area of Lisboa earns on average $€ 929$ and a woman $€ 689$.

Figure 2 confirms that, in general, Lisboa is the region where workers receive the most monthly and the Norte is where they earn the least, and that the earnings are higher in urban areas than in rural regions. On the other hand, in general, labour is better compensated for in the tertiary sector. There are, however, some exceptions such as that for Alentejo, where the labour force receives more in the secondary sector of predominantly urban areas than in the tertiary sector. For example, a worker in a generally urban area of Lisboa earns a monthly average of about $€ 1301$ in the tertiary sector, $€ 1242$ in the secondary sector, and $€ 824$ in the primary sector.

\section{Identification of Indexes Related with the Disparities in the Monthly Average Earnings}

The results presented in Table 1 were obtained through factor analysis following Stata (2017) and Torres-Reyna (n.d.) procedures with the objective of identifying indexes correlated with the several disparities in the monthly average earnings for employees in the Portuguese mainland municipalities over the period 2004-2012. Disparities in the average earnings were considered by taking into account the following criteria: gender, gender in less qualified professions, gender in more qualified professions, gender with qualifications at the higher education level, gender with qualifications equal or inferior to the third cycle of basic education, activity sector, professions, and qualifications.

The results obtained with orthogonal varimax rotation (to reduce the hypothesis of collinearity among the factors found) reveal that the variables analysed are correlated with three indexes (only the results for the factors with variance superior than one were presented) that explains $100 \%$ of the variance (cumulative values).

The rotated factor loadings reveal that the disparities in the monthly average earnings among genders, between genders in less qualified professions, and among genders with qualifications equal to or inferior to the third cycle of basic education explain factor 1 (genders less qualified index), considering only levels of relevance superior than 0.5 . 
Table 1. Factor analysis for the disparities (\%) in the monthly average earnings per employee, considering different criteria.

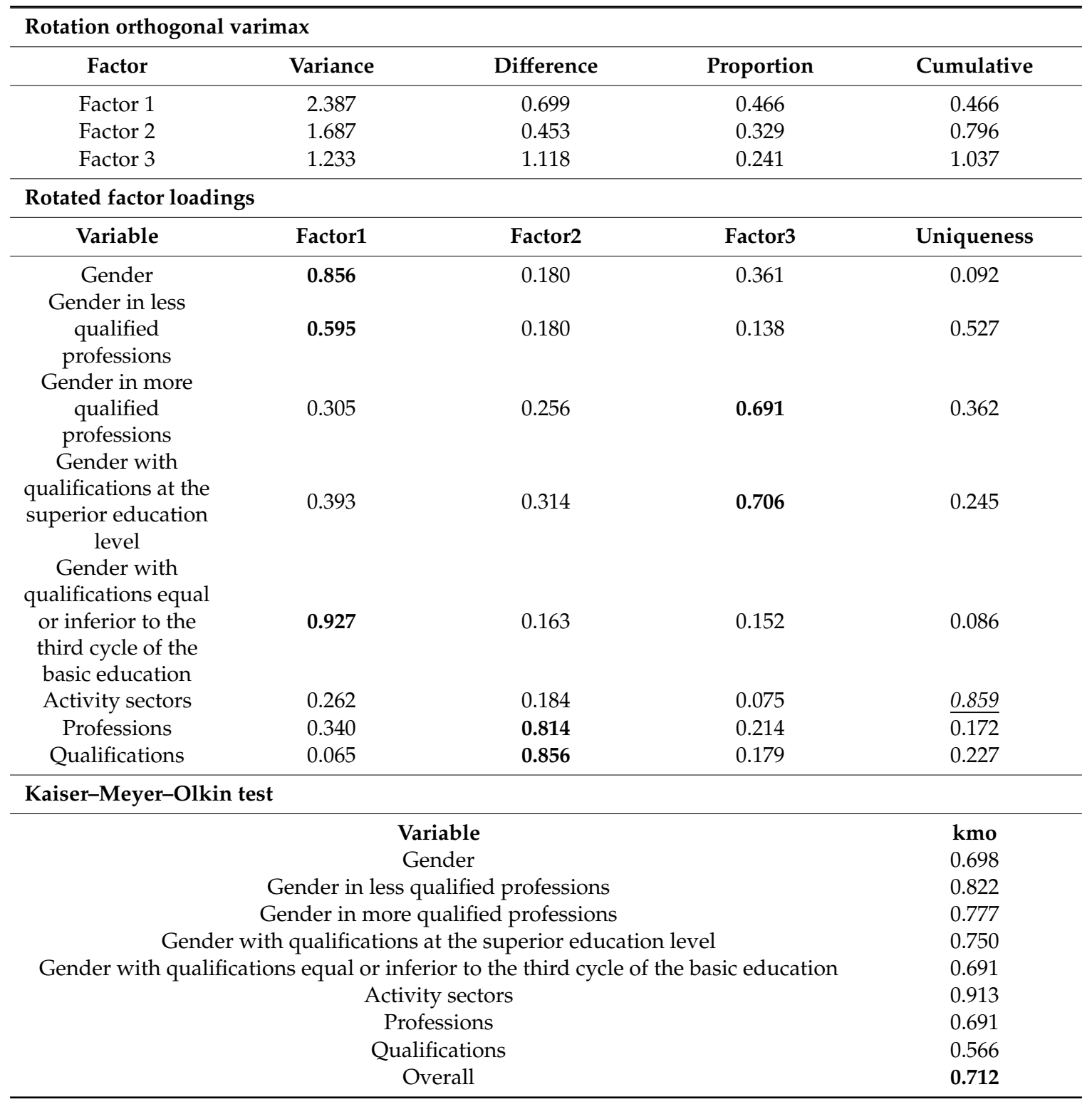

The disparities among genders in more qualified professions and genders with qualifications at the higher education level explain factor 3 (genders more qualified index). The disparities among activities and qualifications explain factor 2 (professions and qualifications index). The disparities between the activity sectors are irrelevant for this model considering that $86 \%$ of its variance is not related with the other variables.

The Kaiser-Meyer-Olkin test with an overall value of 0.712 shows the adequacy of the model considered.

It is worth highlighting that the gender, level of qualification, activity sector, and profession matter for the wages received by employees in Portuguese municipalities. On the other hand, in terms of relevance for the several factors (indexes) explanations, disparities among genders were found, as well as among the level of qualifications obtained and the level of qualifications needed for the professions. The correlation among the level of qualification and the professions was also verified without considering the disparities between genders. Despite the disparities among genders, it is 
interesting to note that qualifications are determinants for the disparities in the average earnings obtained by employees.

\section{Cluster Analysis with the Indexes Found through Factor Analysis}

Following Stata (2017) and Torres-Reyna (n.d.) procedures, the three previously found indexes were considered (genders less qualified index, genders more qualified index, and professions and qualifications index) for the identification of clusters among the 278 Portuguese mainland municipalities. Using Ward's linkage clustering methodology, the dendrogram presented in Figure 3 was obtained. Taking Figure 3 into account, clustering the 278 municipalities into four groups (clusters) was opted for, where clusters 1, 2, 3 and 4 have frequencies of 35, 67, 93 and 83, respectively (Table 2).

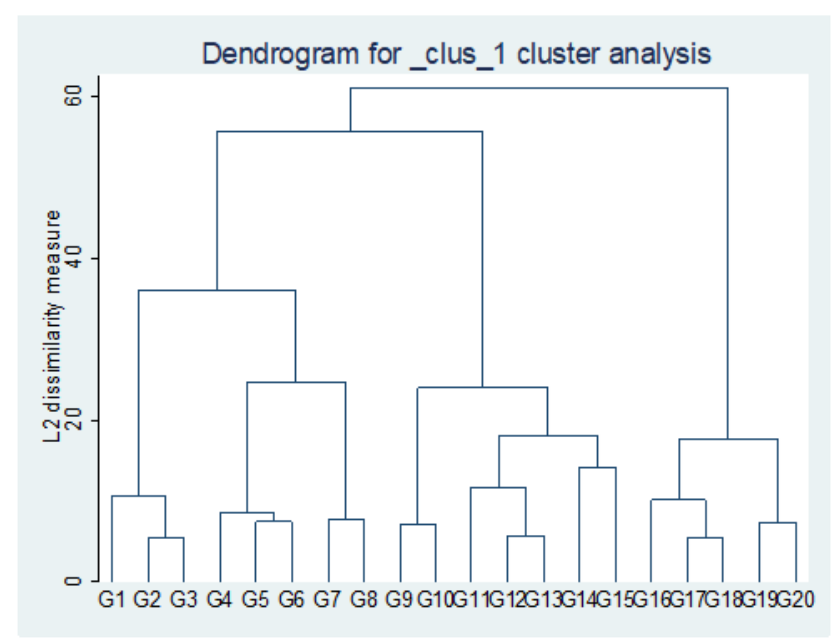

Figure 3. Dendrogram obtained with Ward's linkage clustering.

Table 2. Summary statistics for the clusters obtained.

\begin{tabular}{cccc}
\hline Clusters & Frequency & Percent & Cumulative \\
\hline 1 & 35 & 12.59 & 12.59 \\
2 & 67 & 24.10 & 36.69 \\
3 & 93 & 33.45 & 70.14 \\
4 & 83 & 29.86 & 100.00 \\
\hline Total & $\mathbf{2 7 8}$ & $\mathbf{1 0 0 . 0 0}$ & \\
\hline
\end{tabular}

The average values for the several disparities in each cluster are shown in Figures 4 and 5 and the Portuguese municipalities belonging to each cluster are presented in Table A1 (Appendix) and in Figure 6. From Figures 4 and 5, it is possible to observe that cluster 3 presents higher percentages for all the disparities considered (the greater cluster), with the exception of those related to the qualifications and professions, where cluster 2 has greater scores. With regard to the lower percentages, cluster 1 has inferior disparities for the less qualified gender index, and cluster 4, in general, for the other two indexes. On the other hand, the disparities are higher among professions and qualifications than among genders. In any case, the disparities among clusters seem not to be too exaggerated (a maximum of about 10 percentage points). 


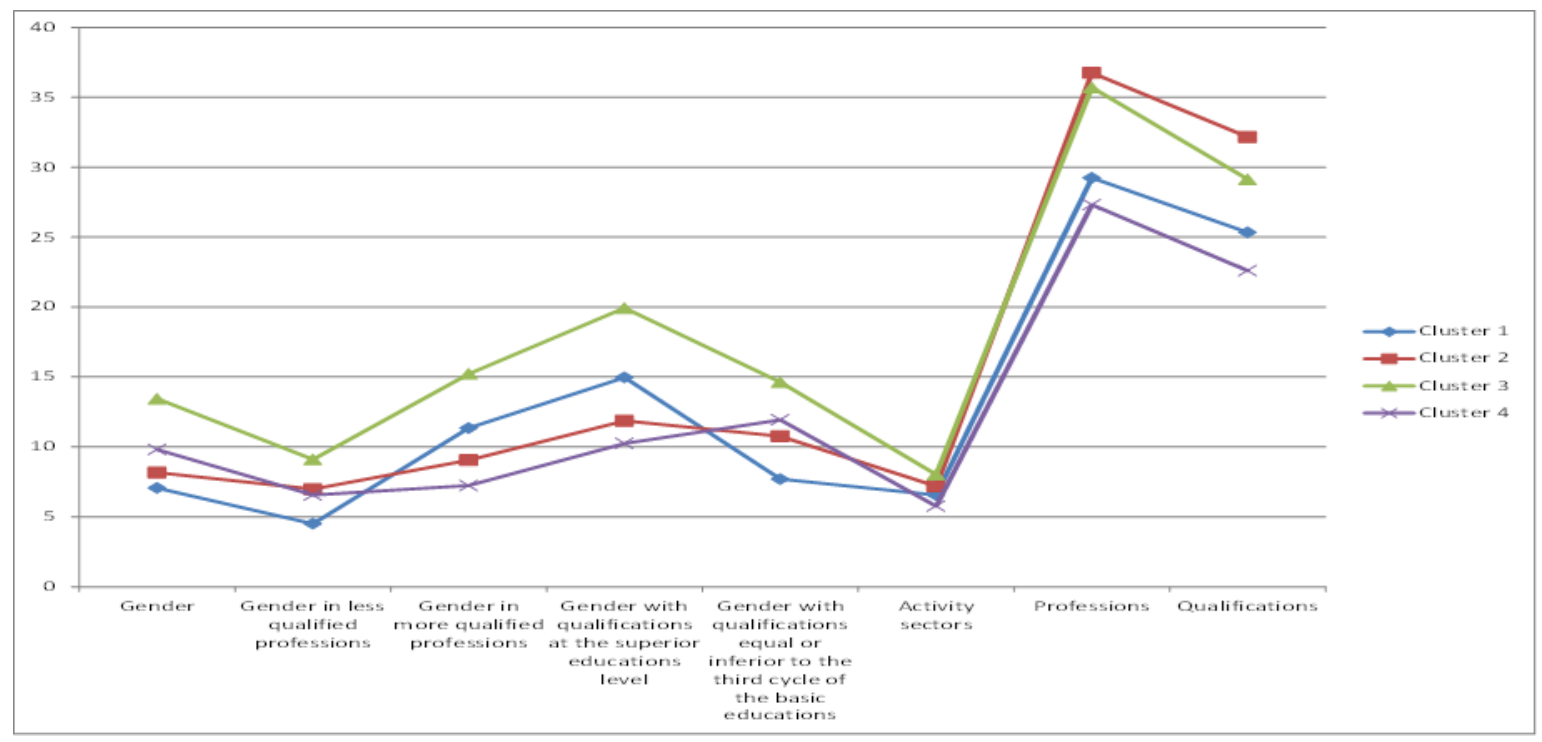

Figure 4. Disparities (average \%) in the monthly average earnings by employees and for all clusters.

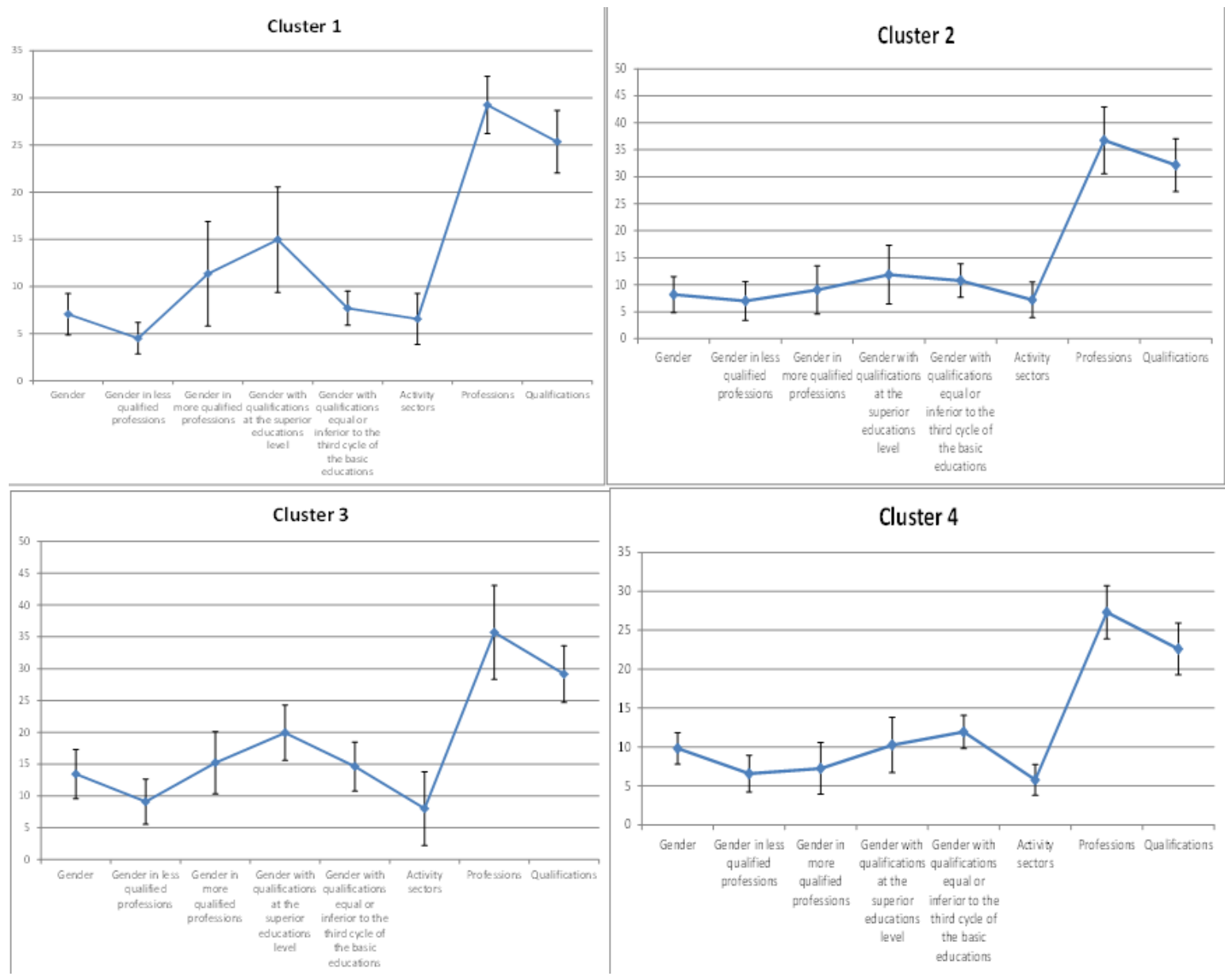

Figure 5. Disparities (averages \% and standard deviations) in the monthly average earnings by employees and for all clusters. 


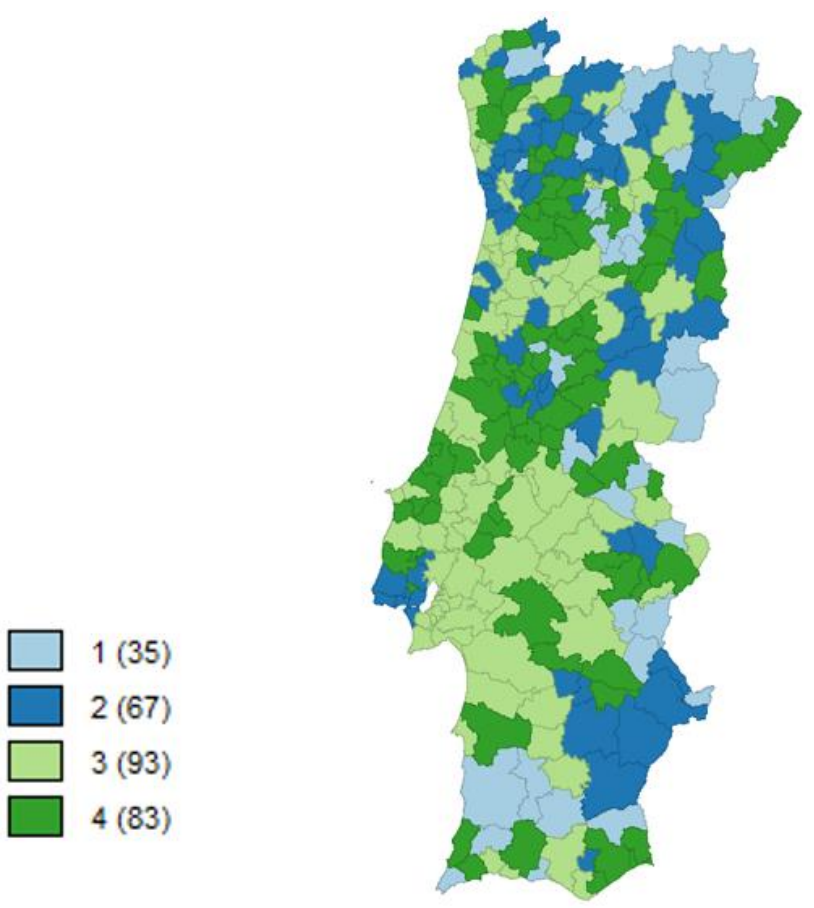

Figure 6. Map with the distribution of the four clusters across the Portuguese municipalities.

Figure 6 shows that it is, indeed, difficult to find a pattern for the distribution of the four clusters across the Portuguese municipalities. However, in an attempt to further explore this map, it seems that cluster 1 may be associated with the municipalities from the north, interior, and south of the Portuguese mainland where the disparities are inferior for the less qualified gender index. The rurality and the incidence of agriculture (with, in general, lower monthly earnings) may be a plausible explanation for these findings. Cluster 2 appears namely in the north, part of the centre, around Lisboa, and in the south interior. Cluster 3 is distributed particularly in the centre (namely along the coastline), including parts from the north and the south of Portugal, and cluster 4 appears across the whole country.

\section{Conclusions}

With this study the intention was to analyse the disparities in the monthly average earnings for employees in the Portuguese mainland municipalities through cluster and factor analysis, over the period 2004-2012, considering the following criteria: gender, gender in less qualified professions, gender in more qualified professions, gender with qualifications at the higher education level, gender with qualifications equal to or inferior to the third cycle of basic education, activity sector, professions, and qualifications.

This study is justified because of the divergences in the income received by the employees across genders, professions, qualifications and activities, which may be a motive for concern for the social cohesion and for the stability of societies (Armaș and Gavriș 2013), namely the disparities among genders and activity sectors. The disparities in monthly earnings received by men and women have relevant impacts on the organization of families and of societies, specifically in terms of equality of gender. The findings presented here may be an interesting contribution toward the design of more adjusted policies for the Portuguese context.

From the data analysis it was found that men earn more than women and that workers receive more in urban areas than in rural areas, which may bring about concerns for social and territorial cohesion. On the other hand, the Norte is the region where the workers earn less, and Lisboa the region with a greater income for labour. In a sectorial analysis, it is observed that labour is better remunerated within the tertiary sector. In fact, the disparities among regions and between urban and rural areas explain, in part, the concentration of population and economic activity in the Lisboa 
region, showing the importance of geographical location in these analyses (Batista-Foguet et al. 2004; Bernard and Saint-Arnaud 2004) and the interrelationships between the several dimensions of societies (Mihokova et al. 2016).

The results from the factor analysis (to find uncorrelated indexes) show that the variables analysed are correlated with three indexes: the less qualified gender index (for the disparities in monthly earnings between genders, among genders in less qualified professions, and among genders with qualifications equal or inferior to the third cycle of basic education); the more qualified gender index (related with the disparities between genders in more qualified professions and among genders with qualifications at the higher education level); and the professions and qualifications index (for the disparities between professions and among qualifications).

With the three indexes found, the Portuguese municipalities were clustered into four clusters through clustering methodologies, where cluster 3 presents higher percentages for all disparities considered, with the exception of those related to qualifications and professions where cluster 2 has greater values, and clusters 1 and 4 have lower disparities for the gender less qualified index and for the other two indexes, respectively. In any case, it would be worth highlighting that the disparities are higher among professions and qualifications, than among genders.

As final remarks, gender, level of qualification, activity sector, and profession are all determinants for the differences in the wages received by employees in Portuguese municipalities. Despite the disparities among genders, it is interesting to verify that qualifications do seem to matter for the disparities in the labour force compensation.

In terms of socioeconomic policies suggestion, it could be important to understand and consider as a benchmark the good examples verified in the municipalities from cluster 4, where, in general, the disparities in the monthly earnings are lower. In the municipalities around Lisboa the employees earn more but it is the region where there are more disparities between qualifications and professions. This should be a concern in the design of social policies. A relevant part of Portugal is included in cluster 3 where a great part of the disparities is higher. Finally, the interior and south of Portugal have lower disparities between less qualified employees, but here there is a problem of economic development that supports these findings.

Relative to the disparities between the monthly earnings for Portuguese employees, it is worth highlighting that in the municipalities around Lisboa there is a social problem; however, in a great part of Portugal it seems that the problem is associated with a lack of economic dynamics and a competitive edge. These are the typical consequences of population and economic activity agglomeration in great cities and the desertification of less developed regions, as highlighted, for example, by the new economic geography (Fujita et al. 2000).

These findings and approaches are specific for the Portuguese context, but may be easily applied in other frameworks to explore and analyse the social justice relative to the average earnings.

Funding: This work is supported by national funds, through the FCT - Portuguese Foundation for Science and Technology under the project UID/SOC/04011/2019.

Conflicts of Interest: The author declares no conflict of interest. 


\section{Appendix A}

Table A1. Grouping the Portuguese municipalities by cluster.

\begin{tabular}{|c|c|}
\hline Municipalities & Cluster \\
\hline \multicolumn{2}{|l|}{ Arcos de Valdevez } \\
\hline \multicolumn{2}{|l|}{ Mondim de Basto } \\
\hline \multicolumn{2}{|l|}{ Paços de Ferreira } \\
\hline \multicolumn{2}{|l|}{ Freixo de Espada à Cinta } \\
\hline \multicolumn{2}{|l|}{ Lamego } \\
\hline \multicolumn{2}{|l|}{ Sernancelhe } \\
\hline \multicolumn{2}{|l|}{ Tarouca } \\
\hline \multicolumn{2}{|l|}{ Vila Flor } \\
\hline \multicolumn{2}{|l|}{ Bragança } \\
\hline \multicolumn{2}{|l|}{ Chaves } \\
\hline \multicolumn{2}{|l|}{ Vila Pouca de Aguiar } \\
\hline \multicolumn{2}{|l|}{ Vimioso } \\
\hline \multicolumn{2}{|l|}{ Vinhais } \\
\hline \multicolumn{2}{|l|}{ Góis } \\
\hline \multicolumn{2}{|l|}{ Vila Nova de Poiares } \\
\hline \multicolumn{2}{|l|}{ Aguiar da Beira } \\
\hline \multicolumn{2}{|l|}{ Sátão } \\
\hline Vila Nova de Paiva & 1 \\
\hline \multicolumn{2}{|l|}{ Mação } \\
\hline \multicolumn{2}{|l|}{ Idanha-a-Nova } \\
\hline \multicolumn{2}{|l|}{ Penamacor } \\
\hline \multicolumn{2}{|l|}{ Odemira } \\
\hline Arronches & \\
\hline Castelo de Vide & \\
\hline Crato & \\
\hline Alandroal & \\
\hline Redondo & \\
\hline Reguengos de Monsaraz & \\
\hline Almodôvar & \\
\hline Barrancos & \\
\hline Ourique & \\
\hline Albufeira & \\
\hline Alcoutim & \\
\hline Monchique & \\
\hline Vila do Bispo & \\
\hline Caminha & \\
\hline Melgaço & \\
\hline Paredes de Coura & \\
\hline Ponte da Barca & \\
\hline Fafe & \\
\hline Guimarães & \\
\hline Póvoa de Lanhoso & \\
\hline Santo Tirso & \\
\hline Trofa & \\
\hline Vila Nova de Famalicão & 2 \\
\hline Espinho & \\
\hline Maia & \\
\hline Matosinhos & \\
\hline Porto & \\
\hline Vila Nova de Gaia & \\
\hline Amarante & \\
\hline Cabeceiras de Basto & \\
\hline Paredes & \\
\hline Penafiel & \\
\hline
\end{tabular}


Table A1. Cont.

\begin{tabular}{|c|c|}
\hline Municipalities & Cluster \\
\hline \multicolumn{2}{|l|}{ Resende } \\
\hline \multicolumn{2}{|l|}{ Ribeira de Pena } \\
\hline \multicolumn{2}{|l|}{ Santa Maria da Feira } \\
\hline \multicolumn{2}{|l|}{ Penedono } \\
\hline \multicolumn{2}{|l|}{ Sabrosa } \\
\hline \multicolumn{2}{|l|}{ Santa Marta de Penaguião } \\
\hline \multicolumn{2}{|l|}{ Torre de Moncorvo } \\
\hline \multicolumn{2}{|l|}{ Vila Real } \\
\hline \multicolumn{2}{|l|}{ Alfândega da Fé } \\
\hline \multicolumn{2}{|l|}{ Macedo de Cavaleiros } \\
\hline \multicolumn{2}{|l|}{ Montalegre } \\
\hline \multicolumn{2}{|l|}{ Murça } \\
\hline \multicolumn{2}{|l|}{ Valpaços } \\
\hline \multicolumn{2}{|l|}{ Aveiro } \\
\hline \multicolumn{2}{|l|}{ Vagos } \\
\hline \multicolumn{2}{|l|}{ Coimbra } \\
\hline \multicolumn{2}{|l|}{ Ansião } \\
\hline \multicolumn{2}{|l|}{ Castanheira de Pêra } \\
\hline \multicolumn{2}{|l|}{ Figueiró dos Vinhos } \\
\hline Pedrógão Grande & \\
\hline Mortágua & \\
\hline Oliveira de Frades & \\
\hline Proença-a-Nova & \\
\hline Gouveia & \\
\hline Figueira de Castelo Rodrigo & \\
\hline Manteigas & \\
\hline Pinhel & \\
\hline Sabugal & \\
\hline Covilhã & \\
\hline Fundão & \\
\hline Arruda dos Vinhos & \\
\hline Amadora & \\
\hline Cascais & \\
\hline Lisboa & \\
\hline Loures & \\
\hline Oeiras & \\
\hline Sintra & \\
\hline Almada & \\
\hline Fronteira & \\
\hline Monforte & \\
\hline Mourão & \\
\hline Alvito & \\
\hline Beja & \\
\hline Cuba & \\
\hline Mértola & \\
\hline Moura & \\
\hline Serpa & \\
\hline São Brás de Alportel & \\
\hline Valença & \\
\hline Viana do Castelo & \\
\hline Vila Nova de Cerveira & \\
\hline Amares & \\
\hline Braga & 2 \\
\hline Esposende & 3 \\
\hline Terras de Bouro & \\
\hline Gondomar & \\
\hline Póvoa de Varzim & \\
\hline Valongo & \\
\hline
\end{tabular}


Table A1. Cont.

\begin{tabular}{|c|c|}
\hline Municipalities & Cluster \\
\hline \multicolumn{2}{|l|}{ Vila do Conde } \\
\hline \multicolumn{2}{|l|}{ Oliveira de Azeméis } \\
\hline \multicolumn{2}{|l|}{ São João da Madeira } \\
\hline \multicolumn{2}{|l|}{ Vale de Cambra } \\
\hline \multicolumn{2}{|l|}{ Alijó } \\
\hline \multicolumn{2}{|l|}{ Mesão Frio } \\
\hline \multicolumn{2}{|l|}{ Peso da Régua } \\
\hline \multicolumn{2}{|l|}{ São João da Pesqueira } \\
\hline \multicolumn{2}{|l|}{ Tabuaço } \\
\hline \multicolumn{2}{|l|}{ Boticas } \\
\hline \multicolumn{2}{|l|}{ Mirandela } \\
\hline \multicolumn{2}{|l|}{ Águeda } \\
\hline \multicolumn{2}{|l|}{ Albergaria-a-Velha } \\
\hline \multicolumn{2}{|l|}{ Anadia } \\
\hline \multicolumn{2}{|l|}{ Estarreja } \\
\hline \multicolumn{2}{|l|}{ Ílhavo } \\
\hline \multicolumn{2}{|l|}{ Mealhada } \\
\hline \multicolumn{2}{|l|}{ Murtosa } \\
\hline Oliveira do Bairro & \\
\hline Ovar & \\
\hline Cantanhede & \\
\hline Figueira da Foz & \\
\hline Batalha & \\
\hline Leiria & \\
\hline Marinha Grande & \\
\hline Carregal do Sal & \\
\hline Mangualde & \\
\hline Nelas & \\
\hline Santa Comba Dão & \\
\hline Tondela & \\
\hline Viseu & \\
\hline Vouzela & \\
\hline Seia & \\
\hline Guarda & \\
\hline Castelo Branco & \\
\hline Vila Velha de Ródão & \\
\hline Belmonte & \\
\hline Alenquer & \\
\hline Óbidos & \\
\hline Peniche & \\
\hline Torres Vedras & \\
\hline Abrantes & \\
\hline Alcanena & \\
\hline Constância & \\
\hline Entroncamento & \\
\hline Torres Novas & \\
\hline Vila Nova da Barquinha & \\
\hline Vila Franca de Xira & \\
\hline Alcochete & \\
\hline Barreiro & \\
\hline Moita & \\
\hline Montijo & \\
\hline Palmela & \\
\hline Seixal & \\
\hline Sesimbra & \\
\hline Setúbal & \\
\hline Alcácer do Sal & \\
\hline Grândola & \\
\hline Sines & \\
\hline
\end{tabular}


Table A1. Cont.

\begin{tabular}{|c|c|}
\hline Municipalities & Cluster \\
\hline \multicolumn{2}{|l|}{ Alter do Chão } \\
\hline \multicolumn{2}{|l|}{ Avis } \\
\hline \multicolumn{2}{|l|}{ Campo Maior } \\
\hline \multicolumn{2}{|l|}{ Mora } \\
\hline \multicolumn{2}{|l|}{ Ponte de Sor } \\
\hline \multicolumn{2}{|l|}{ Portalegre } \\
\hline \multicolumn{2}{|l|}{ Arraiolos } \\
\hline \multicolumn{2}{|l|}{ Évora } \\
\hline \multicolumn{2}{|l|}{ Vendas Novas } \\
\hline \multicolumn{2}{|l|}{ Vila Viçosa } \\
\hline \multicolumn{2}{|l|}{ Aljustrel } \\
\hline \multicolumn{2}{|l|}{ Castro Verde } \\
\hline \multicolumn{2}{|l|}{ Ferreira do Alentejo } \\
\hline \multicolumn{2}{|l|}{ Azambuja } \\
\hline \multicolumn{2}{|l|}{ Benavente } \\
\hline \multicolumn{2}{|l|}{ Cartaxo } \\
\hline \multicolumn{2}{|l|}{ Chamusca } \\
\hline \multicolumn{2}{|l|}{ Coruche } \\
\hline Rio Maior & \\
\hline Santarém & \\
\hline Faro & \\
\hline Lagoa & \\
\hline Loulé & \\
\hline Portimão & \\
\hline Monção & \\
\hline Ponte de Lima & \\
\hline Barcelos & \\
\hline Vila Verde & \\
\hline Vieira do Minho & \\
\hline Vizela & \\
\hline Baião & \\
\hline Castelo de Paiva & \\
\hline Celorico de Basto & \\
\hline Cinfães & \\
\hline Felgueiras & \\
\hline Lousada & \\
\hline Marco de Canaveses & \\
\hline Arouca & \\
\hline Armamar & \\
\hline Carrazeda de Ansiães & \\
\hline Moimenta da Beira & \\
\hline Vila Nova de Foz Côa & 4 \\
\hline Miranda do Douro & \\
\hline Mogadouro & \\
\hline Sever do Vouga & \\
\hline Condeixa-a-Nova & \\
\hline Mira & \\
\hline Montemor-o-Velho & \\
\hline Penacova & \\
\hline Soure & \\
\hline Pombal & \\
\hline Porto de Mós & \\
\hline Alvaiázere & \\
\hline Arganil & \\
\hline Lousã & \\
\hline Miranda do Corvo & \\
\hline Oliveira do Hospital & \\
\hline Pampilhosa da Serra & \\
\hline Penela & \\
\hline
\end{tabular}


Table A1. Cont.

\begin{tabular}{|c|c|}
\hline Municipalities & Cluster \\
\hline \multicolumn{2}{|l|}{ Tábua } \\
\hline \multicolumn{2}{|l|}{ Castro Daire } \\
\hline \multicolumn{2}{|l|}{ Penalva do Castelo } \\
\hline \multicolumn{2}{|l|}{ São Pedro do Sul } \\
\hline \multicolumn{2}{|l|}{ Oleiros } \\
\hline \multicolumn{2}{|l|}{ Sertã } \\
\hline \multicolumn{2}{|l|}{ Vila de Rei } \\
\hline \multicolumn{2}{|l|}{ Fornos de Algodres } \\
\hline \multicolumn{2}{|l|}{ Almeida } \\
\hline \multicolumn{2}{|l|}{ Celorico da Beira } \\
\hline \multicolumn{2}{|l|}{ Mêda } \\
\hline \multicolumn{2}{|l|}{ Trancoso } \\
\hline \multicolumn{2}{|l|}{ Alcobaça } \\
\hline \multicolumn{2}{|l|}{ Bombarral } \\
\hline \multicolumn{2}{|l|}{ Cadaval } \\
\hline \multicolumn{2}{|l|}{ Caldas da Rainha } \\
\hline \multicolumn{2}{|l|}{ Lourinhã } \\
\hline \multicolumn{2}{|l|}{ Nazaré } \\
\hline \multicolumn{2}{|l|}{ Sobral de Monte Agraço } \\
\hline \multicolumn{2}{|l|}{ Ferreira do Zêzere } \\
\hline \multicolumn{2}{|l|}{ Ourém } \\
\hline \multicolumn{2}{|l|}{ Sardoal } \\
\hline \multicolumn{2}{|l|}{ Tomar } \\
\hline \multicolumn{2}{|l|}{ Mafra } \\
\hline Odivelas & \\
\hline Santiago do Cacém & \\
\hline Elvas & \\
\hline Gavião & \\
\hline Marvão & \\
\hline Nisa & \\
\hline Borba & \\
\hline Estremoz & \\
\hline Montemor-o-Novo & \\
\hline Portel & \\
\hline Sousel & \\
\hline Viana do Alentejo & \\
\hline Vidigueira & \\
\hline Almeirim & \\
\hline Alpiarça & \\
\hline Golegã & \\
\hline Salvaterra de Magos & \\
\hline Aljezur & \\
\hline Castro Marim & \\
\hline Lagos & \\
\hline Olhão & \\
\hline Silves & \\
\hline Tavira & \\
\hline Vila Real de Santo António & \\
\hline
\end{tabular}

\section{References}

Armaș, Iuliana, and Alexandru Gavriș. 2013. Social vulnerability assessment using spatial multi-criteria analysis (SEVI model) and the Social Vulnerability Index (SoVI model) - A case study for Bucharest, Romania. Natural Hazards and Earth System Sciences 13: 1481-99. [CrossRef]

Aschauer, Wolfgang. 2016. Societal malaise and ethnocentrism in the European Union: monitoring societal change by focusing on EU citizens' perceptions of crisis. Historical Social Research 41: 307-59. 
Batista-Foguet, J. M., J. Fortiana, C. Currie, and J. R. Villalbii. 2004. Socio-economic indexes in surveys for comparisons between countries. Social Indicators Research 67: 315-32. [CrossRef]

Bernard, Paul, and Sébastien Saint-Arnaud. 2004. Du pareil au même? La position des quatre principales provinces canadiennes dans l'univers des régimes providentiels. The Canadian Journal of Sociology / Cahiers canadiens de sociologie 29: 209-39. [CrossRef]

Castellano, Rosalia, Gennaro Punzo, and Antonella Rocca. 2018. The generational perspective of gender gap in wages and education in southern Europe. Review of Social Economy 76: 227-58. [CrossRef]

Castellano, Rosalia, Gaetano Musella, and Gennaro Punzo. 2017. Structure of the labour market and wage inequality: Evidence from European countries. Quality \& Quantity 51: 2191-218.

Cernakova, Veronika, and Oto Hudec. 2012. Quality of Life: Typology of European Cities Based on Cluster Analysis. Ekonomie a Management 15: 34-48.

D'Ancona, M. Angeles Cea. 2009. The complex detection of racism and xenophobia through survey methods. A step forward in their measurement. Revista Espanola De Investigaciones Sociologicas 125: 13-45.

Dilly, Oliver, and Reinhard F. Hüttl. 2009. Top-down and Europe-wide versus bottom-up and intra-regional identification of key issues for sustainability impact assessment. Environmental Science \& Policy 12: 1168-76.

De Dominicis, Laura, Raymond J. G. M. Florax, and Henri L. F. de Groot. 2013. Regional clusters of innovative activity in Europe: Are social capital and geographical proximity key determinants? Applied Economics 45: 2325-35. [CrossRef]

Fernandez, Paulo, Sandra Mourato, Madalena Moreira, and Luísa Pereira. 2016. A new approach for computing a flood vulnerability index using cluster analysis. Physics and Chemistry of the Earth, Parts A/B/C 94: 47-55. [CrossRef]

Figari, Francesco, Manos Matsaganis, and Holly Sutherland. 2013. Are European social safety nets tight enough? Coverage and adequacy of Minimum Income schemes in 14 EU countries. International Journal of Social Welfare 22: 3-14. [CrossRef]

Fujita, Masahisa, Paul Krugman, and Anthony J. Venables. 2000. The Spatial Economy: Cities, Regions, and International Trade. Cambridge: MIT Press.

Garnsey, Elizabeth, and Paul Heffernan. 2005. High-technology clustering through spin-out and attraction: The Cambridge case. Regional Studies 39: 1127-44. [CrossRef]

Goedemé, Tim. 2013. How much Confidence can we have in EU-SILC? Complex Sample Designs and the Standard Error of the Europe 2020 Poverty Indicators. Social Indicators Research 110: 89-110. [CrossRef]

Higgins, Paul, Josep Campanera, and Alexandre Nobajas. 2014. Quality of life and spatial inequality in London. European Urban and Regional Studies 21: 42-59. [CrossRef]

INE. 2017. Several Statistics. Available online: https://www.ine.pt/xportal/xmain?xpid=INE\&xpgid=ine_base_ dados (accessed on 8 February 2017).

Kammer, Andreas, Judith Niehues, and Andreas Peichl. 2012. Welfare regimes and welfare state outcomes in Europe. Journal of European Social Policy 22: 455-71. [CrossRef]

Manitiu, Dorel N., and Giulio Pedrini. 2016. Urban smartness and sustainability in Europe. An ex ante assessment of environmental, social and cultural domains. European Planning Studies 24: 1766-87. [CrossRef]

Martinho, Vítor João Pereira Domingues. 2016. Forestry activity in Portugal within the context of the European Union: a cluster in agricultural economics for sustainable development. Environment, Development and Sustainability 18: 1339-97. [CrossRef]

Mascherini, Massimiliano, Daniele Vidoni, and Anna Rita Manca. 2011. Exploring the Determinants of Civil Participation in 14 European Countries: One-Size-Fits None. European Sociological Review 27: 790-807. [CrossRef]

McCollum, David, Elina Apsite-Berina, Maris Berzins, and Zaiga Krisjane. 2017. Overcoming the crisis: The changing profile and trajectories of Latvian migrants. Journal of Ethnic and Migration Studies 43: 1508-25. [CrossRef]

Mihokova, Lucia, Alena Andrejovska, and Slavomira Martinkova. 2016. Categorization of corporate taxation in the European Union countries using cluster analysis: A comparative study. Економічний часопис-XXI 160: 4-8. [CrossRef]

Mitchell, Eva. 2009. Financial Support of Families in the Czech Republic and Slovakia from the European Perspective: More Similar than Different? Sociologia 41: 223-46. 
Padilla, Cindy M., Wahida Kihal-Talantikit, Sandra Perez, and Severine Deguen. 2016. Use of geographic indicators of healthcare, environment and socioeconomic factors to characterize environmental health disparities. Environmental Health 15: 79. [CrossRef] [PubMed]

Pepin, Joanna R. 2019. Beliefs About Money in Families: Balancing Unity, Autonomy, and Gender Equality. Journal of Marriage and Family 81: 361-79. [CrossRef]

Perugini, Cristiano, and Fabrizio Pompei. 2016. Employment protection and wage inequality within education groups in Europe. Journal of Policy Modeling 38: 810-36. [CrossRef]

Saraceno, Chiara, and Wolfgang Keck. 2010. Can We Identify Intergenerational Policy Regimes in Europe? European Societies 12: 675-96. [CrossRef]

Shaker, R. Richard, and Sara L. Zubalsky. 2015. Examining patterns of sustainability across Europe: A multivariate and spatial assessment of 25 composite indices. International Journal of Sustainable Development $\mathcal{E}$ World Ecology 22: 1-13.

Sousa, Liliana, Helena Galante, António Batel, and Pedro Hespanha. 2003. Observing cities' social inequalities: A cartographic case study of Aveiro, Portugal. Cities 20: 241-52. [CrossRef]

Stata. 2017. Data Analysis and Statistical Software. Available online: http://www.stata.com/ (accessed on 8 February 2017).

Stuczynski, Tomasz, Grzegorz Siebielec, Renata Korzeniowska-Puculek, Piotr Koza, Pudelko Rafal, Artur Lopatka, and Monika Kowalik. 2009. Geographical location and key sensitivity issues of post-industrial regions in Europe. Environmental Monitoring and Assessment 151: 77-91. [CrossRef]

Tappeiner, Gottfried, Christoph Hauser, and Janette Walde. 2008. Regional knowledge spillovers: Fact or artifact? Research Policy 37: 861-74. [CrossRef]

Torres-Reyna, O. n.d. Getting Started in Factor Analysis (using Stata 10) (ver. 1.5). Available online: https: //www.princeton.edu/ \{\}otorres/Factor.pdf (accessed on 8 February 2017).

(C) 2019 by the author. Licensee MDPI, Basel, Switzerland. This article is an open access article distributed under the terms and conditions of the Creative Commons Attribution (CC BY) license (http://creativecommons.org/licenses/by/4.0/). 